\title{
Changes in piglet tissue composition at birth in response to increasing maternal intake of long-chain $n-3$ polyunsaturated fatty acids are non-linear
}

\author{
J. A. Rooke*, A. G. Sinclair and M. Ewen \\ Animal Biology Division, SAC, Craibstone Estate, Aberdeen AB21 9YA, UK \\ (Received 31 January 2001 - Revised 9 April 2001 - Accepted 6 May 2001)
}

\begin{abstract}
Addition of marine oils containing long-chain $n-3$ polyunsaturated fatty acids to the diet of pregnant sows may reduce piglet mortality. In previous experiments, when marine oils have been fed to pregnant sows, improvements in piglet tissue $22: 6 n-3$ status have been accompanied by potentially undesirable decreases in 20:4n-6. The objective of the present experiment was to establish an amount of dietary salmon oil which would enhance piglet $22: 6 n-3$ status while minimising reductions in $20: 4 n-6$. Twenty-four pregnant multiparous sows were used in the experiment which began on day 60 of pregnancy (gestation length $115 \mathrm{~d}$ ). To give four diets, salmon oil was added in increasing amounts $(0,5,10$ and $20 \mathrm{~g} / \mathrm{kg}$ diet $)$ to a basal diet; the diets were made isoenergetic by adding palm oil to each diet to give a total of $20 \mathrm{~g}$ oil $/ \mathrm{kg}$ diet. Diets were offered to the sows in fixed amounts $(2.5 \mathrm{~kg} / \mathrm{d})$ until parturition. Piglet tissue samples (brain, liver and retina) were obtained at birth before consumption of colostrum. The greatest increase in piglet tissue $22: 6 n-3$ proportions occurred between 0 and $5 \mathrm{~g}$ salmon oil $/ \mathrm{kg}$ diet, with only small increases between 10 and $20 \mathrm{~g}$ salmon oil $/ \mathrm{kg}$ diet. In contrast, tissue 20:4n-6 proportions declined progressively as the amount of salmon oil fed to the sow increased. In brain, the change in the value $22: 6 n-3 / 22: 5 n-6$ was greatest between 0 and $5 \mathrm{~g}$ salmon oil $/ \mathrm{kg}$ diet, whereas in liver the value increased linearly with added salmon oil. In addition, piglet brain weight $(\mathrm{g} / \mathrm{kg}$ live weight) increased to a maximum at $10 \mathrm{~g}$ salmon oil $/ \mathrm{kg}$ diet. The optimum amount of supplementary salmon oil in the current experiment, defined as that which gave the greatest response in brain $22: 6 n-3$ proportions with minimum reduction in $20: 4 n-6$, was $10 \mathrm{~g}$ salmon oil $/ \mathrm{kg}$ diet. This corresponds to an intake of approximately $2.4 \mathrm{~g} 20: 5 n-3$ plus $3.6 \mathrm{~g}$ $22: 6 n-3 / \mathrm{d}$ or $0.6 \%$ digestible energy.
\end{abstract}

Pregnancy: Dietary fatty acids: Piglet tissue fatty acids

The long-chain polyunsaturated fatty acids, arachidonic acid 20:4n-6 and docosahexaenoic acid $(22: 6 n-3)$ are important structural lipid components in biomembranes. In addition, $20: 4 n-6$ is a precursor for prostaglandin biosynthesis and may be a second messenger (Kurlak \& Stephenson, 1999). Docosahexaenoic acid is a major constituent of retinal and synaptosomal membranes, and is therefore important for the development and function of brain and retina (for review, see Uauy et al. 2000). It also has an important role in prevention of heart disease, is antiinflammatory (Nettleton, 1995) and is involved in control of gene expression (Raclot et al. 1997; Takahashi \& Ide, 2000). Inadequate maternal $n-3$ fatty acid nutrition has been shown to have adverse effects, such as impaired visual and cognitive development, in offspring of man and experimental animals (Uauy et al. 2000). In the pig, as in man (Clandinin et al. 1980), brain growth and therefore accretion of $22: 6 n-3$ is greatest in the last third of pregnancy (Sweasey et al. 1976; Passingham, 1985). Commercial pig diets are based on cereals and protein feeds which do not contain long chain $n-3$ fatty acids. Supplementation of the diet of the sow with $18: 3 n-3$ has been shown to be ineffective in increasing piglet tissue $22: 6 n-3$ proportions due to a combination of limited maternal and fetal synthesis of $22: 6 n-3$ from $18: 3 n-3$ (Rooke et al. 2000). Thus, there may be a demand for $22: 6 n-3$ by the piglet in utero not met by current sow diets.

Mortality between birth and weaning is an important and intractable source of loss to the pig industry (Varley, 1995). A contributory factor to mortality is the vigour of the

\footnotetext{
Abbreviations: DE, digestible energy; SO, S5, S10, S20, experimental treatments providing 0, 5, 10 and $20 \mathrm{~g}$ salmon oil/kg diet respectively.

* Corresponding author: Dr. J. A. Rooke, fax +44 1224 711292, email j.rooke@ab.sac.ac.uk
} 
newborn piglet and it has been an ongoing experimental hypothesis that the absence of a supply of long chain $n-3$ fatty acids has in part been responsible; indeed it has been recently shown that including salmon oil $(16.5 \mathrm{~g} / \mathrm{kg}$ diet $)$ in the diet of pregnant sows reduced preweaning piglet mortality (Cordoba et al. 2000). However, salmon oil supplementation reduced mean piglet birth weight, which in itself is a negative risk factor for piglet mortality (Roehe \& Kalm, 2000). Carlson et al. (1992, 1993) have observed a positive correlation in human infants between weight at birth and 20:4n-6 status, and Arbuckle et al. (1991) noted a depression in brain weight in piglets fed milk containing high concentrations of $22: 6 n-3$. Thus, the depression in piglet birth weight observed by Cordoba et al. (2000) may be associated with depressions in $20: 4 n-6$ status as a result of feeding fish oil to the sow. In previous experiments (Rooke et al. 1999, 2000) feeding fish oil to the sow has resulted in depressions in tissue $20: 4 n-6$ status of piglets. In other studies in which increasing amounts of fish oil have been fed to milk-fed piglets (Arbuckle et al. 1991) or rodents (Huang et al. 1992; Wainwright et al. 1992; Ward et al. 1998) changes in tissue $22: 6 n-3$ and $20: 4 n-6$ profiles have been non-linear. Thus, the amount of salmon oil fed previously (Cordoba et al. 2000) may not have been optimal. Since there is no dose-response information available for the pregnant sow, it was the objective of the present experiment to define the relationship between the amount of salmon oil fed to the pregnant sow and responses as measured by piglet tissue fatty acid concentrations at birth. As current requirements for pigs (National Research Council, 1998) do not give requirements for $n-3$ fatty acids, it was also hoped to make an estimate of the long-chain $n-3$ fatty acid requirement of the pregnant sow.

\section{Materials and methods}

The experiment was carried out at Tillycorthie Pig Unit, SAC, Aberdeen. The experimental procedures were carried out under the Animal (Scientific Procedures) Act 1986 and were subject to review by the SAC Animal Experiments Committee.

\section{Animals}

Twenty-four multiparous sows (Large White $\times$ Landraces; Newsham Hybrid Pigs Ltd, Malton, North Yorkshire) were used in the experiment which began 59 (SEM 0.8) d after the sows were mated to Large White boars. Sows were allocated to treatments (six sows per treatment) based on live weight and back-fat thickness. Mean parity (4.5 (SEM 0.28)) did not differ between treatments.

\section{Experimental treatments}

The dietary treatments which were offered to the sows differed in their fatty acid composition. The basal diet was formulated to minimise inclusion of $n-3$ fatty acids and contained $(\mathrm{g} / \mathrm{kg})$ milled barley 600 , wheatfeed 188 , soyabean meal 135, fishmeal 52, mineral and vitamin mix 25 (Sowvite 110; Norvite Ltd, Insch, Aberdeenshire, UK). The mineral and vitamin mix was fortified with $\alpha$ tocopherol acetate $(200 \mathrm{mg} / \mathrm{kg}$ diet $)$ as an antioxidant. The oils included in the diets were salmon oil (United Fish Products, Aberdeen, UK) as a source of long-chain $n-3$ fatty acids and palm oil to maintain diets isoenergetically but to minimise inclusion of essential fatty acids from sources other than salmon oil. The four experimental treatments

Table 1. Composition of diets containing increasing amounts of salmon oil offered to pregnant sows from day 60 of gestation (Mean values with their standard errors of difference for four observations per diet)

\begin{tabular}{|c|c|c|c|c|c|c|}
\hline & \multicolumn{4}{|c|}{ Treatment† } & \multirow[b]{2}{*}{ SED } & \multirow{2}{*}{$\begin{array}{c}\text { Statistical significance } \\
\text { of differences } \\
\text { between treatments }\end{array}$} \\
\hline & So & S5 & $\mathrm{S} 10$ & $\mathrm{~S} 20$ & & \\
\hline \multicolumn{7}{|l|}{ Chemical composition (g/kg DM) } \\
\hline $\mathrm{DM}(\mathrm{g} / \mathrm{kg})$ & 876 & 877 & 877 & 875 & & \\
\hline Crude protein $(\mathrm{N} \times 6.25)$ & 149 & 150 & 150 & 157 & & \\
\hline Ether extract & 48 & 39 & 42 & 39 & & \\
\hline Neutral-detergent fibre & 176 & 148 & 144 & 151 & & \\
\hline Ash & 62 & 60 & 64 & 62 & & \\
\hline Digestible energy (MJ/kg DM) & $14 \cdot 9$ & $15 \cdot 2$ & $15 \cdot 2$ & $15 \cdot 2$ & & \\
\hline \multicolumn{7}{|l|}{ Fatty acids (g/100 g fatty acids) } \\
\hline Total saturated & $38 \cdot 7$ & $32 \cdot 8$ & $30 \cdot 7$ & $27 \cdot 4$ & $2 \cdot 84$ & * \\
\hline $\begin{array}{l}\text { Total monounsaturated } \\
n-6 \text { Fatty acids }\end{array}$ & $17 \cdot 2$ & $21 \cdot 3$ & $19 \cdot 1$ & $18 \cdot 6$ & $1 \cdot 61$ & NS \\
\hline Total & $40 \cdot 1$ & 39.5 & $40 \cdot 7$ & $40 \cdot 5$ & $2 \cdot 49$ & NS \\
\hline $18: 2$ & 39.9 & $39 \cdot 0$ & $40 \cdot 2$ & 39.2 & 2.44 & NS \\
\hline $20: 4$ & $<0.1$ & 0.1 & 0.1 & 0.5 & $0 \cdot 17$ & NS \\
\hline \multicolumn{7}{|l|}{$n-3$ Fatty acids } \\
\hline Total & $4 \cdot 0$ & $5 \cdot 8$ & 8.6 & 11.9 & 1.22 & $* * *$ \\
\hline $18: 3$ & 3.8 & 3.3 & $3 \cdot 8$ & $4 \cdot 1$ & 0.31 & NS \\
\hline $20: 5$ & ND & 0.9 & $1 \cdot 8$ & 3.0 & 0.44 & $* \star *$ \\
\hline $22: 5$ & $<0.1$ & 0.5 & 0.8 & 1.6 & $0 \cdot 16$ & $\star \star \star *$ \\
\hline $22: 6$ & 0.1 & 1.6 & $2 \cdot 9$ & $4 \cdot 8$ & 0.89 & $\star \star \star \star ~$ \\
\hline$n-6: n-3$ & $10 \cdot 2$ & $6 \cdot 8$ & 4.9 & 3.6 & 0.59 & 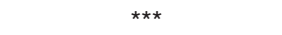 \\
\hline
\end{tabular}

$\mathrm{ND}$, none detected; S0, S5, S10, S20, experimental treatments providing 0, 5, 10 and $20 \mathrm{~g}$ salmon oil/kg diet.

${ }^{\star} P<0.05,{ }^{* * *} P<0.001$.

†For details of diets and procedures, see p. 463. 
contained 0 (S0), 5 (S5), 10 (S10) and 20 (S20) g salmon oil $/ \mathrm{kg}$ diet with palm oil used to adjust total oil content to $20 \mathrm{~g} / \mathrm{kg}$ diet. Batches of feed with added oil were prepared twice weekly in a $50 \mathrm{~kg}$ capacity horizontal mixer. Diets S0 and S20 were prepared by mixing the oils with the basal diet and diets S5 and S10 by mixing together appropriate quantities of S0 and S20. The feed was stored with air excluded at room temperature in sealed plastic bags. The diets were offered in fixed daily amounts $(2.5 \mathrm{~kg} / \mathrm{d})$, all of which was consumed. Samples of each diet were obtained when prepared and stored at $-20^{\circ} \mathrm{C}$. Feed samples were bulked (three individual samples) to give six samples for each diet. The composition of the diets, which is shown in Table 1, did not differ between batches of diet.

\section{Experimental procedures}

Sows. The sows were weighed, back-fat thickness measured ultrasonically at the $\mathrm{P}_{2}$ position and samples of blood obtained on three occasions during pregnancy: day 59 (start range 55-67), day 88 (range 82-94) and day 110 (range 106-113) of pregnancy (normal gestation length $115 \mathrm{~d}$ ) counting from the day of first service. Blood samples were obtained from each sow by jugular venepuncture into evacuated tubes containing KEDTA $(18 \mathrm{mg})$. Plasma was prepared from the blood samples by centrifugation at $2000 \mathrm{~g}$ for $20 \mathrm{~min}$ and stored at $-20^{\circ} \mathrm{C}$ until analysed. The sows were transferred to farrowing crates several days before parturition. On day 113 of pregnancy, sows were injected intramuscularly with $2 \mathrm{ml}$ of a synthetic prostaglandin analogue (Cloprostenol; Planate, Coopers Animal Health, Crewe, Ches.; $92 \mathrm{mg} / \mathrm{ml}$ ) at about 11.00 hours to induce farrowing on day 114. A sample of colostrum was obtained by hand from each sow immediately after farrowing was complete from as many teats as possible and stored at $-20^{\circ} \mathrm{C}$.

Farrowing and piglets. All farrowings were attended. After farrowing each piglet was removed from the sow, dried and placed in a heated box. On completion of farrowing (30 min after expulsion of the placenta), the weight of each piglet was recorded. Piglets were selected from each litter as follows: two piglets per litter were selected, except for litters of eight or less in number from which one piglet was selected. The piglets selected were representative of the mean litter weight. Piglets were anaesthetized by intraperitoneal injection of sodium pentobarbitone (Euthatal; Rhone Merieux, Harlow, Essex; $200 \mathrm{mg} / \mathrm{ml}$ ) and then killed by an overdose of sodium pentobarbitone; immediately afterwards a blood sample was obtained by cardiac puncture into a tube containing KEDTA $(18 \mathrm{mg})$. The brain, liver, and eyes were removed and the weights of liver and brain recorded. The eyes were freed from connective tissue and the anterior half of the eyeball and contents of the eye removed. The posterior half of the eyeball, liver and brain were immediately frozen and stored at $-20^{\circ} \mathrm{C}$ until analysis. Plasma was prepared from the blood samples as described earlier.

\section{Analytical procedures}

Food samples were analysed for DM $\left(80^{\circ} \mathrm{C}\right.$ for $\left.18 \mathrm{~h}\right)$, ash $\left(550^{\circ} \mathrm{C}\right.$ for $\left.18 \mathrm{~h}\right)$, crude protein $(\mathrm{N} \times 6 \cdot 25)$ by the Kjeldahl method and acid ethyl ether extract and neutral-detergent fibre according to Ministry of Agriculture, Fisheries and Food (1992). The digestible energy (DE) concentrations of the diets were calculated according to Ministry of Agriculture, Fisheries and Food (1993). Food and tissue samples were homogenized in a suitable excess of chloroform-methanol (2:1, ratio, v/v) containing pentadecanoic acid $(15: 0)$ as internal standard and extracts of total lipid in chloroform prepared (Christie, 1982). Samples of the posterior half of the eyeball were vigorously mixed with saline $(9 \mathrm{~g} \mathrm{NaCl} / \mathrm{l})$ to remove the retinal cells from connective tissue before the retinal cells were extracted. Fatty acid methyl esters were prepared by transmethylation by refluxing the lipid in methanol-toluene- $-\mathrm{H}_{2} \mathrm{SO}_{4}$ (20:10:1, by vol.) for $30 \mathrm{~min}$ (Christie et al. 1970). The fatty acid methyl esters were extracted into hexane before chromatography. Fatty acid methyl esters were separated by GLC using a capillary column (HP225, $30 \mathrm{~m} \times 0.25 \mathrm{~mm}$, film thickness $0 \cdot 25 \mu \mathrm{m}$; Hewlett-Packard Ltd, Stockport, Ches.) in a Phillips PU4500 chromatograph. Peak identities were verified by comparison with the retention times of standard fatty acid methyl esters (Sigma Chemical Co. Ltd, Poole, Dorset). Peak areas were determined with the aid of a Kontron DS450 Data System (Kontron Instruments, Watford, Herts) and quantified with reference to the internal standard and a known standard (Supelco 37 Component mix; Supelco, Poole, Dorset) for peak identification.

\section{Statistics}

Data from two sows were excluded; one sow was found to have entered the experiment when only $40 \mathrm{~d}$ pregnant and the second sow only produced one piglet. The data relating to sow plasma samples were analysed by ANOVA using Genstat 5 (Lawes Agricultural Trust; Clarendon Press, Oxford) using a repeated measures ANOVA. Effects of diet, sampling time and diet $\times$ sampling time interactions were assessed using orthogonal polynomials. Since, depending on litter size, one or two piglets per litter were killed, data relating to piglet tissue composition were analysed using a split-plot ANOVA using the REML procedure of Genstat, and diet effects assessed from Wald statistics and $\chi^{2}$ tests.

\section{Results}

Sows

The sows gained weight between the start of the experiment on day 59 of pregnancy (265 (SEM 3.9) kg) and day 110 (284 (SEM 3.7) kg) whereas back-fat thickness was little changed (day 59, $22(\operatorname{SEM} 1 \cdot 1) \mathrm{mm}$; day 110, $23($ SEM 1.1) mm); there were no differences between treatments in weight or back-fat thickness.

There were no differences between treatments (Table 2) in sow plasma triacylglycerol or non-esterified fatty acid concentrations; however plasma triacylglycerol concentrations increased with time (linear effect, $P<0 \cdot 01$ ). Plasma fatty acid proportions changed with time and treatment (Table 2). Irrespective of treatment, the proportions of $20: 4 n-6$ in sow plasma decreased as the experiment progressed. The proportions of the $n-3$ acids 
Table 2. Effect of stage of pregnancy and amount of salmon oil offered to pregnant sows on plasma non-esterified fatty acid (NEFA) and triacylglycerol (TG) concentrations (mmol/l) and proportions of plasma fatty acid ( $\mathrm{g} / 100 \mathrm{~g}$ total fatty acids)

(Mean values with their standard errors of difference between diets $(n 18)$ and times $(n 24)$ )

\begin{tabular}{|c|c|c|c|c|c|c|c|c|c|c|c|c|c|c|}
\hline \multirow{2}{*}{$\begin{array}{l}\text { Day ... } \\
\text { Treatment† ... }\end{array}$} & \multirow[t]{2}{*}{$59 \ddagger$} & \multicolumn{4}{|c|}{88} & \multicolumn{4}{|c|}{110} & \multicolumn{2}{|c|}{ SED } & \multicolumn{3}{|c|}{ Statistical significance of effects of: } \\
\hline & & So & S5 & S10 & S20 & So & S5 & S10 & S20 & Diet & Time & Diet & Time & Interaction \\
\hline NEFA & $0 \cdot 17$ & $0 \cdot 15$ & 0.21 & $0 \cdot 16$ & $0 \cdot 14$ & 0.21 & $0 \cdot 16$ & 0.19 & $0 \cdot 17$ & 0.037 & 0.020 & NS & NS & NS \\
\hline TG & 0.47 & 0.53 & 0.56 & 0.67 & 0.58 & 0.62 & 0.55 & 0.70 & 0.55 & 0.083 & 0.037 & NS & $L^{\star *}$ & NS \\
\hline \multicolumn{15}{|l|}{ Fatty acids } \\
\hline \multicolumn{14}{|l|}{ Monounsaturated } & NS \\
\hline Total & $27 \cdot 1$ & $31 \cdot 1$ & $29 \cdot 2$ & $24 \cdot 8$ & $27 \cdot 8$ & $31 \cdot 7$ & $29 \cdot 4$ & 29.7 & $28 \cdot 1$ & $2 \cdot 01$ & 0.84 & NS & $L^{* \star}$ & NS \\
\hline \multicolumn{14}{|l|}{$n-6$ Fatty acids } & *** \\
\hline Total & $29 \cdot 4$ & $25 \cdot 9$ & $24 \cdot 9$ & $29 \cdot 1$ & $21 \cdot 7$ & $20 \cdot 4$ & $22 \cdot 9$ & $22 \cdot 5$ & $23 \cdot 5$ & $2 \cdot 74$ & $1 \cdot 76$ & NS & $L^{* \star *}$ & NS \\
\hline $18: 2$ & $22 \cdot 4$ & $20 \cdot 2$ & $19 \cdot 3$ & $23 \cdot 6$ & $17 \cdot 5$ & $15 \cdot 7$ & $17 \cdot 6$ & $18 \cdot 0$ & $19 \cdot 6$ & $2 \cdot 00$ & 1.44 & NS & $L^{\star \star}$ & NS \\
\hline \multirow{2}{*}{\multicolumn{15}{|c|}{$n-3$ Fatty acids }} \\
\hline & & & & & & & & & & & & & & \\
\hline Total & $6 \cdot 1$ & $6 \cdot 6$ & $6 \cdot 0$ & $9 \cdot 8$ & $11 \cdot 3$ & $5 \cdot 3$ & $8 \cdot 1$ & $7 \cdot 8$ & $10 \cdot 5$ & 1.04 & 0.74 & $L^{*}$ & $L^{*}, Q^{*}$ & ** \\
\hline $18: 3$ & 1.6 & 1.3 & $1 \cdot 1$ & 1.3 & $1 \cdot 1$ & 1.2 & 1.0 & $1 \cdot 1$ & 1.4 & 0.33 & 0.13 & NS & $L^{\star \star}$ & * \\
\hline $20: 5$ & $2 \cdot 0$ & $1 \cdot 2$ & 1.8 & $2 \cdot 9$ & $4 \cdot 0$ & $1 \cdot 1$ & $2 \cdot 6$ & 2.5 & $3 \cdot 4$ & 0.60 & 0.57 & NS & NS & * \\
\hline $22: 6$ & 1.3 & $2 \cdot 8$ & 1.8 & $3 \cdot 6$ & $4 \cdot 3$ & 1.9 & $2 \cdot 8$ & 3.0 & $4 \cdot 2$ & 0.53 & 0.35 & $L^{* \star}$ & $L^{* * *}, Q^{\star *}$ & NS \\
\hline$n-6: n-3$ & 5.5 & $4 \cdot 7$ & $4 \cdot 4$ & $2 \cdot 7$ & $2 \cdot 0$ & $5 \cdot 2$ & $2 \cdot 6$ & $2 \cdot 9$ & $2 \cdot 3$ & $0 \cdot 70$ & 0.44 & NS & $L^{\star \star \star}, Q^{\star}$ & $\star *$ \\
\hline
\end{tabular}

$\mathrm{L}$, linear effect of diet or time; Q, quadratic effect of diet or time; S0, S5, S10, S20, experimental treatments providing 0, 5, 10 and $20 \mathrm{~g}$ salmon oil/kg diet respectively.

${ }^{*} P<0.05,{ }^{* *} P<0.01,{ }^{* \star *} P<0.001$.

†For details of diets and procedures, see p. 463 and Table 1 . 
Table 3. Fatty acid composition ( $\mathrm{g} / 100 \mathrm{~g}$ fatty acids) of colostrum obtained from sows offered differing amounts of salmon oil

(Mean values with their standard errors of difference for four observations per treatment)

\begin{tabular}{|c|c|c|c|c|c|c|}
\hline Treatment† ... & So & S5 & $\mathrm{S} 10$ & $\mathrm{~S} 20$ & SED & $\begin{array}{c}\text { Statistical significance } \\
\text { of effects of diet }\end{array}$ \\
\hline $\begin{array}{l}\text { Total saturated fatty acids } \\
\text { Monounsaturated }\end{array}$ & $32 \cdot 5$ & $32 \cdot 0$ & 31.9 & $28 \cdot 5$ & 1.53 & $L^{*}$ \\
\hline Total & 38.8 & 37.6 & 34.3 & 34.4 & 1.29 & $L^{* *}$ \\
\hline $\begin{array}{c}18: 1 n-9 \\
n-6 \text { Fatty acids }\end{array}$ & 31.9 & $29 \cdot 8$ & $27 \cdot 4$ & $26 \cdot 8$ & $1 \cdot 21$ & $\mathrm{~L}^{* * *}$ \\
\hline Total & $25 \cdot 5$ & $25 \cdot 8$ & $26 \cdot 3$ & $27 \cdot 2$ & 1.44 & NS \\
\hline $18: 2$ & 22.9 & 23.5 & 23.8 & $25 \cdot 0$ & $1 \cdot 20$ & NS \\
\hline $20: 4$ & 1.6 & $1 \cdot 2$ & 1.6 & $1 \cdot 1$ & 0.243 & NS \\
\hline$n-3$ Fatty acids & & & & & & \\
\hline Total & 2.9 & $4 \cdot 7$ & $7 \cdot 5$ & $10 \cdot 0$ & 1.019 & $L^{* * *}$ \\
\hline $18: 3$ & $1 \cdot 7$ & $1 \cdot 8$ & $2 \cdot 1$ & $2 \cdot 2$ & $0 \cdot 171$ & $L^{* *}$ \\
\hline $20: 5$ & 0.3 & 0.3 & 0.8 & $1 \cdot 1$ & 0.335 & $L^{*}$ \\
\hline $22: 5$ & 0.8 & 1.3 & $2 \cdot 1$ & 2.5 & 0.072 & $\mathrm{~L}^{*}$ \\
\hline $22: 6$ & $0 \cdot 1$ & 1.5 & $2 \cdot 2$ & $3 \cdot 7$ & 0.056 & $\mathrm{~L}^{\star * *}$ \\
\hline$n-6: n-3$ & $10 \cdot 0$ & $5 \cdot 6$ & $3 \cdot 6$ & $2 \cdot 6$ & 0.93 & $L^{\star * \star}, Q^{*}$ \\
\hline
\end{tabular}

$\mathrm{L}, \mathrm{Q}$, linear and quadratic effects respectively of diet; S0, S5, S10, S20, experimental treatments providing $0,5,10$ and $20 \mathrm{~g}$ salmon oil $/ \mathrm{kg}$ diet respectively.

${ }^{\star} P<0.05,{ }^{* *} P<0.01,{ }^{* *} P<0.001$

†For details of diets and procedures, see p. 463 and Table 1.

were increased by feeding salmon oil. For treatments S10 and S20, plasma 22:6n-3 proportions increased between days 59 and 88 and then remained constant or declined whereas for S5, 22:6n-3 increased throughout the experiment.

The fatty acid composition of sow colostrum broadly reflected the amount of salmon oil included in the diet (Table 3). The proportions of long-chain polyunsaturated $n-3$ acids increased linearly with salmon oil inclusion, while those of $n-6$ were largely unaffected by the treatments imposed.
Piglets

As the amount of salmon oil included in the diet increased, the size of litters born to the sows decreased (linear effect, $P<0.05$; SED 1.63 ) from 14.0 for S0 to 10.3 for S20. However, there were no differences in total litter weight between treatments $(15.7 \mathrm{~kg})$ as the average weight of piglets tended to increase as the amount of salmon oil included in the maternal diet increased (from S0, $1.36 \mathrm{~kg}$ to S20, $1.50 \mathrm{~kg}$; NS, SED 0.108). Median preweaning mortality was $0 \cdot 10$ for piglets born alive (lower and upper quartiles, 0

Table 4. Plasma total fatty acid proportions ( $\mathrm{g} / 100 \mathrm{~g}$ fatty acids) from piglets born to sows offered differing amounts of salmon oil

(Mean values with their standard errors of difference for ten observations per treatment)

\begin{tabular}{|c|c|c|c|c|c|c|}
\hline Treatment† & So & S5 & $\mathrm{S} 10$ & $\mathrm{~S} 20$ & SED & $\begin{array}{l}\text { Statistical significance } \\
\text { of effects of diet }\end{array}$ \\
\hline $\begin{array}{l}\text { Total saturated fatty acids } \\
\text { Monounsaturated fatty acids }\end{array}$ & $44 \cdot 4$ & $48 \cdot 5$ & $43 \cdot 1$ & $46 \cdot 1$ & $2 \cdot 89$ & NS \\
\hline Total & $29 \cdot 1$ & 28.9 & 31.9 & $31 \cdot 2$ & 1.41 & NS \\
\hline $18: 1 n-9$ & $19 \cdot 8$ & $18 \cdot 8$ & $21 \cdot 6$ & $21 \cdot 3$ & $1 \cdot 16$ & NS \\
\hline$n-6$ Fatty acids & & & & & & \\
\hline Total & $16 \cdot 4$ & $15 \cdot 6$ & $16 \cdot 2$ & $13 \cdot 9$ & $1 \cdot 24$ & NS \\
\hline $18: 2$ & 4.3 & 3.8 & 4.8 & 4.4 & 0.68 & NS \\
\hline $20: 4$ & $10 \cdot 2$ & $8 \cdot 3$ & 8.1 & $6 \cdot 8$ & 0.84 & $L^{* *}$ \\
\hline$n$-3 Fatty acids & & & & & & \\
\hline Total & $7 \cdot 6$ & $6 \cdot 2$ & $7 \cdot 8$ & $8 \cdot 4$ & 0.75 & NS \\
\hline $18: 3$ & 0.7 & 0.4 & 0.4 & $0 \cdot 8$ & 0.20 & NS \\
\hline $20: 5$ & 1.9 & 1.0 & 1.6 & $2 \cdot 3$ & 0.41 & NS \\
\hline $22: 5$ & 0.4 & 0.4 & 0.7 & 0.6 & 0.06 & NS \\
\hline $22: 6$ & $5 \cdot 0$ & 4.4 & $5 \cdot 1$ & $4 \cdot 7$ & 0.76 & NS \\
\hline$n-6: n-3$ & $2 \cdot 5$ & $2 \cdot 6$ & $2 \cdot 0$ & $1 \cdot 8$ & 0.21 & $L^{*}$ \\
\hline
\end{tabular}

$\mathrm{L}, \mathrm{Q}$, linear and quadratic effects respectively of diet; S0, S5, S10, S20, experimental treatments providing 0,5 , 10 and $20 \mathrm{~g}$ salmon oil/ $/ \mathrm{kg}$ diet respectively.

${ }^{\star} P<0.05,{ }^{*} P<0.01$.

†For details of diets and procedures, see p. 463 and Table 1. 
Table 5. Brain total fatty acid proportions ( $\mathrm{g} / 100 \mathrm{~g}$ fatty acids) from piglets born to sows offered differing amounts of salmon oil

(Mean values with their standard errors of difference for nine observations per treatment)

\begin{tabular}{|c|c|c|c|c|c|c|}
\hline Treatment† ... & So & S5 & $\mathrm{S} 10$ & $\mathrm{~S} 20$ & SED & $\begin{array}{c}\text { Statistical significance } \\
\text { of effects of diet }\end{array}$ \\
\hline $\begin{array}{l}\text { Total saturated fatty acids } \\
\text { Monounsaturated fatty acids }\end{array}$ & $40 \cdot 7$ & 39.9 & $41 \cdot 4$ & 41.7 & 0.82 & NS \\
\hline Total & $16 \cdot 5$ & $16 \cdot 6$ & $15 \cdot 4$ & $16 \cdot 7$ & 0.74 & NS \\
\hline $18: 1 n-9$ & $10 \cdot 7$ & $10 \cdot 8$ & $9 \cdot 8$ & $10 \cdot 7$ & 0.62 & NS \\
\hline \multicolumn{7}{|l|}{$n-6$ Fatty acids } \\
\hline Total & $24 \cdot 6$ & $22 \cdot 7$ & $22 \cdot 0$ & $20 \cdot 7$ & 0.64 & $L^{* \star *}$ \\
\hline $18: 2$ & 0.4 & 0.4 & 0.4 & 0.6 & 0.11 & NS \\
\hline $20: 4$ & $15 \cdot 1$ & $14 \cdot 8$ & $14 \cdot 4$ & 13.9 & 0.53 & $L^{*}$ \\
\hline $22: 4$ & $5 \cdot 7$ & $5 \cdot 1$ & $5 \cdot 2$ & 4.4 & 0.25 & $L^{* \star *}$ \\
\hline $22: 5$ & $3 \cdot 0$ & $2 \cdot 0$ & 1.7 & 1.4 & 0.18 & $L^{\star \star \star \star}, Q^{\star \star \star}$ \\
\hline \multicolumn{7}{|l|}{$n-3$ Fatty acids } \\
\hline Total & $18 \cdot 2$ & $20 \cdot 3$ & $21 \cdot 2$ & $20 \cdot 8$ & 0.83 & $L^{* *}, Q^{*}$ \\
\hline $20: 5$ & 0.2 & 0.2 & $0 \cdot 1$ & 0.3 & 0.21 & NS \\
\hline $22: 5$ & 0.2 & 0.3 & 0.4 & 0.6 & $0 \cdot 18$ & $L^{*}$ \\
\hline $22: 6$ & $17 \cdot 8$ & $19 \cdot 6$ & $20 \cdot 6$ & $19 \cdot 8$ & 0.79 & $L^{*}, Q^{*}$ \\
\hline$n-6: n-3$ & 1.4 & $1 \cdot 1$ & 1.0 & 1.0 & 0.06 & $\mathrm{~L}^{\star \star \star}, \mathrm{Q}^{\star \star}$ \\
\hline $22: 6 n-3 / 22: 5 n-6$ & $6 \cdot 1$ & $9 \cdot 9$ & $12 \cdot 4$ & 13.9 & 0.61 & $L^{\star \star \star}, Q^{\star \star \star}$ \\
\hline
\end{tabular}

$\mathrm{L}, \mathrm{Q}$, linear and quadratic effects respectively of diet; S0, S5, S10, S20, experimental treatments providing $0,5,10$ and $20 \mathrm{~g}$ salmon oil $/ \mathrm{kg}$ diet respectively.

${ }^{\star} P<0.05,{ }^{\star \star} P<0.01,{ }^{\star \star *} P<0.001$.

†For details of diets and procedures, see p. 463 and Table 1.

and 0.19 respectively). In piglets selected for tissue sampling there was a quadratic relationship $(P<0.05$, SED 1.92) between brain weight and treatment, such that brain weight ( $\mathrm{g} / \mathrm{kg}$ live weight) increased from 25.2 for treatment S0 to a maximum of 30.6 for treatment S10 and then decreased to $26 \cdot 7$ for treatment $S 20$.

The effects of maternal diet on the fatty acid composition of piglet plasma were relatively small (Table 4). The proportions of 20:4n-6 declined significantly $(P<0 \cdot 01)$ and $20: 5 n-3$ tended to increase $(P<0 \cdot 10)$ as the amount of salmon oil included in the diet increased. Thus, $n-6: n-3$ fatty acids in piglet plasma declined as the amount of salmon oil in the maternal diet increased. Compared with maternal plasma, piglet plasma contained greater proportions of the polyunsaturated fatty acids $20: 4 n-6$ and $22: 6 n-3$.

The proportions of $n-6$ acids in piglet brain declined linearly in response to increasing amounts of salmon oil (Table 5). In contrast, there was a quadratic component in the increases in total $n-3$ acids and of $22: 6 n-3$ in response to

Table 6. Retinal total fatty acid proportions ( $\mathrm{g} / 100 \mathrm{~g}$ fatty acids) from piglets born to sows offered differing amounts of salmon oil

\begin{tabular}{|c|c|c|c|c|c|c|}
\hline Treatment† ... & so & S5 & $\mathrm{S} 10$ & $\mathrm{~S} 20$ & SED & $\begin{array}{l}\text { Statistical significance } \\
\text { of effects of diet }\end{array}$ \\
\hline $\begin{array}{l}\text { Total saturated fatty acids } \\
\text { Monounsaturated fatty acids }\end{array}$ & 33.9 & $34 \cdot 1$ & $34 \cdot 2$ & $33 \cdot 8$ & 1.57 & NS \\
\hline Total & $20 \cdot 0$ & 18.9 & $18 \cdot 7$ & $20 \cdot 2$ & 0.97 & NS \\
\hline $\begin{array}{c}18: 1 n-9 \\
n-6 \text { Fatty acids }\end{array}$ & $13 \cdot 6$ & $12 \cdot 7$ & $13 \cdot 0$ & $14 \cdot 1$ & $0 \cdot 81$ & NS \\
\hline Total & $25 \cdot 0$ & $23 \cdot 3$ & $22 \cdot 7$ & $21 \cdot 7$ & 1.33 & $L^{*}$ \\
\hline $18: 2$ & $2 \cdot 5$ & $2 \cdot 3$ & $2 \cdot 6$ & $2 \cdot 4$ & 0.33 & NS \\
\hline $20: 4$ & $16 \cdot 7$ & $16 \cdot 2$ & $16 \cdot 0$ & $14 \cdot 8$ & 1.02 & $L^{*}$ \\
\hline $22: 4$ & $2 \cdot 9$ & $2 \cdot 7$ & $2 \cdot 1$ & $2 \cdot 1$ & 0.25 & $L^{* *}$ \\
\hline $22: 5$ & $1 \cdot 6$ & $1 \cdot 3$ & 0.9 & 1.4 & 0.28 & NS \\
\hline$n-3$ Fatty acids & & & & & & \\
\hline Total & $21 \cdot 1$ & 23.5 & $24 \cdot 3$ & $24 \cdot 3$ & 1.85 & NS \\
\hline $20: 5$ & 1.4 & $1 \cdot 3$ & 1.6 & $2 \cdot 2$ & 0.46 & NS \\
\hline $22: 5$ & 0.7 & $1 \cdot 8$ & $2 \cdot 3$ & 1.8 & 0.55 & NS \\
\hline $22: 6$ & $18 \cdot 6$ & $20 \cdot 2$ & $20 \cdot 2$ & $20 \cdot 1$ & 1.92 & NS \\
\hline$n-6: n-3$ & $1 \cdot 2$ & $1 \cdot 0$ & 1.0 & 0.9 & $0 \cdot 12$ & $L^{*}$ \\
\hline $22: 6 n-3 / 22: 5 n-6$ & $11 \cdot 8$ & $18 \cdot 8$ & $23 \cdot 1$ & $19 \cdot 0$ & $4 \cdot 34$ & $Q^{*}$ \\
\hline
\end{tabular}

$\mathrm{L}, \mathrm{Q}$, linear and quadratic effects respectively of diet; S0, S5, S10, S20, experimental treatments providing $0,5,10$ and $20 \mathrm{~g}$ salmon oil $/ \mathrm{kg}$ diet respectively.

${ }^{*} P<0.05,{ }^{* *} P<0.01$.

†For details of diets and procedures, see p. 463 and Table 1. 
Table 7. Liver total fatty acid proportions ( $g / 100 \mathrm{~g}$ fatty acids) from piglets born to sows offered differing amounts of salmon oil

(Mean values with their standard errors of difference for nine observations per treatment)

\begin{tabular}{|c|c|c|c|c|c|c|}
\hline Treatment† ... & So & S5 & $\mathrm{S} 10$ & $\mathrm{~S} 20$ & SED & $\begin{array}{c}\text { Statistical significance } \\
\text { of effects of diet }\end{array}$ \\
\hline $\begin{array}{l}\text { Total saturated fatty acids } \\
\text { Monounsaturated fatty acids }\end{array}$ & $36 \cdot 4$ & $36 \cdot 2$ & $36 \cdot 4$ & $36 \cdot 6$ & 1.08 & NS \\
\hline Total & 33.3 & $30 \cdot 6$ & $31 \cdot 2$ & $32 \cdot 4$ & $2 \cdot 13$ & NS \\
\hline $\begin{array}{c}18: 1 n-9 \\
n-6 \text { Fatty acids }\end{array}$ & $19 \cdot 2$ & $17 \cdot 9$ & $18 \cdot 9$ & $18 \cdot 5$ & 1.53 & NS \\
\hline Total & $22 \cdot 1$ & $20 \cdot 9$ & $19 \cdot 0$ & $16 \cdot 9$ & $1 \cdot 12$ & $L^{* * *}$ \\
\hline $18: 2$ & $5 \cdot 3$ & $5 \cdot 1$ & $5 \cdot 0$ & 4.9 & 0.39 & NS \\
\hline $20: 4$ & 13.5 & $13 \cdot 0$ & 11.7 & $9 \cdot 6$ & 1.30 & $L^{\star *}$ \\
\hline $22: 4$ & 0.7 & 0.7 & 0.5 & 0.4 & 0.14 & $L^{*}$ \\
\hline $22: 5$ & $1 \cdot 6$ & 1.3 & $1 \cdot 1$ & 1.0 & 0.15 & $L^{* \star *}$ \\
\hline$n$-3 Fatty acids & & & & & & \\
\hline Total & $8 \cdot 2$ & $12 \cdot 1$ & $13 \cdot 1$ & $13 \cdot 8$ & $1 \cdot 37$ & $L^{\star \star \star}$ \\
\hline $18: 3$ & 0.2 & 0.2 & 0.2 & 0.2 & 0.03 & NS \\
\hline $20: 5$ & 0.7 & 1.4 & $2 \cdot 0$ & $2 \cdot 6$ & 0.30 & $\mathrm{~L}^{* * *}$ \\
\hline $22: 5$ & 0.6 & 0.9 & 1.0 & $1 \cdot 1$ & 0.20 & $L^{\star \star \star}$ \\
\hline $22: 6$ & $6 \cdot 8$ & $9 \cdot 6$ & $9 \cdot 9$ & $10 \cdot 0$ & $1 \cdot 24$ & $L^{*}$ \\
\hline$n-6: n-3$ & $2 \cdot 8$ & 1.8 & 1.5 & $1 \cdot 2$ & 0.06 & $L^{\star \star \star}, Q^{\star \star *}$ \\
\hline $22: 6 n-3 / 22: 5 n-6$ & $4 \cdot 3$ & $7 \cdot 6$ & 9.5 & $11 \cdot 5$ & 1.55 & $L^{\star \star *}$ \\
\hline
\end{tabular}

L, Q, linear and quadratic effects respectively of diet; S0, S5, S10, S20, experimental treatments providing $0,5,10$ and $20 \mathrm{~g}$ salmon oil $/ \mathrm{kg}$ diet respectively.

${ }^{\star} P<0.05,{ }^{* \star} P<0.01,{ }^{\star * \star} P<0.001$.

†For details of diets and procedures, see p. 463 and Table 1.

salmon oil supplementation. Most of the increase took place between treatments S0 and S5, with little or no change between treatments S10 and S20. Although responses were less marked and in general non-significant, the same pattern was observed for retina (Table 6). A different pattern of responses in fatty acid composition was observed for liver (Table 7). In common with brain and retina there were linear decreases in $n-6$ fatty acid proportions. However, instead of quadratic responses for the $n-3$ acids as observed for brain and retina, linear responses to salmon oil inclusion were observed, and therefore the increase in $n-3$ proportions did not reach a plateau at treatment S10. Rather, the increase continued, although the greatest response was still achieved between treatments S0 and S5. The 22:6n-3/22:5n-6 values and the proportions of $20: 4 n-6$ for brain, retina and liver are shown in Fig. 1.

\section{Discussion}

The main objective of the experiment was to quantify responses in piglet tissue fatty acid composition at birth to increasing maternal salmon oil intake. To date, effects of increasing maternal fatty acid intake on fatty acid composition of the neonate have been reported only in laboratory rodents (Huang et al. 1992; Wainwright et al. 1992; Bourre et al. 1993). The oil used in the experiment was the same oil $(16.5 \mathrm{~g} / \mathrm{kg})$ as that used by Cordoba et al. (2000), who reported reductions in piglet mortality when including salmon oil in the diet, although the composition of the basal diet differed. It was therefore planned that the present experiment might suggest a lesser amount of dietary oil inclusion which would maximise increases in piglet tissue $22: 6 n-3$ whilst minimising any reduction in $20: 4 n-6$ which may have been a contributory factor for the depression in piglet birth weight observed by Cordoba et al. (2000). Although litter size declined as the amount of salmon oil included in the diet increased, this finding was unlikely to have been caused by inclusion of salmon oil in the diet on day 60 of pregnancy, as litter size in the pig is determined by ovulation rate and prenatal death, the majority of which occurs before day 30 of pregnancy (Ashworth \& Pickard, 1998).

The responses of maternal and piglet tissues to inclusion of fish oil in the diet were similar to those previously observed with pigs (Leskanitch \& Noble, 1999; Rooke et al. 1999, 2000). Thus, maternal plasma and colostrum longchain polyunsaturated fatty acids directly reflected the nutritional status of the sow. However, the proportions of $20: 4 n-6$ and $22: 6 n-3$ were greater in piglet plasma at birth than in maternal plasma at $110 \mathrm{~d}$ of gestation probably as a result of selective uptake across the placenta at least in part due to the specificity of placental fatty acid-binding protein (Campbell et al. 1998). As also observed in previous experiments, brain and retina contained higher proportions of the long-chain polyunsaturated fatty acids than liver, which in turn contained greater proportions than plasma; quantitatively brain and retina were less responsive to maternal supplementation than liver and plasma.

Responses of $20: 4 n-6$ and $22: 6 n-3$ in piglet tissues to increasing salmon oil inclusion differed. The 22:6n-3/ $22: 5 n-6$ value, a more sensitive indicator of $22: 6 n-3$ status than $22: 6 n-3$ proportions per se (Innis, 2000), increased up to an inclusion of $10 \mathrm{~g}$ salmon oil $/ \mathrm{kg}$ diet and then reached a plateau. The decline in $20: 4 n-6$ proportions in all tissues, however, was linear. Similar, although not identical, patterns of response have been observed in other animal 

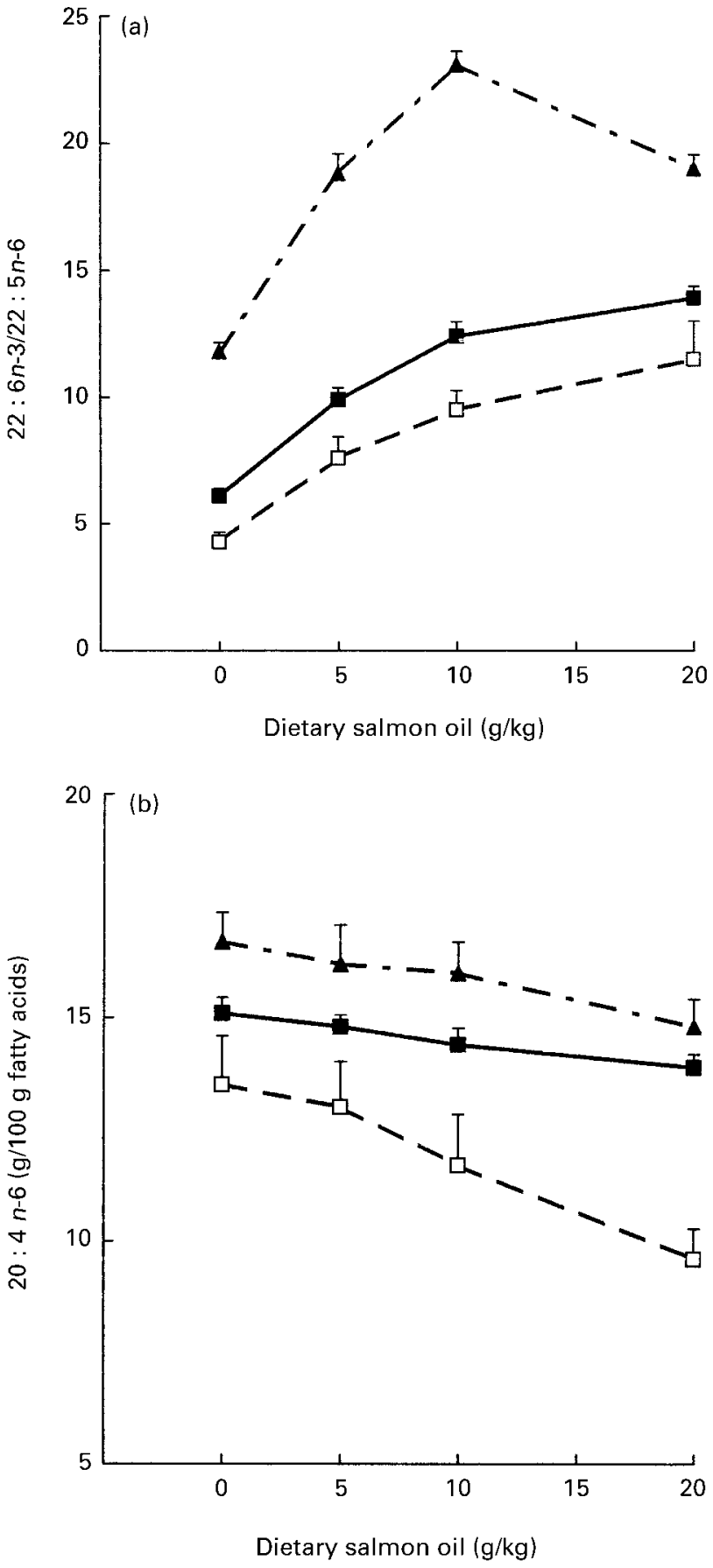

Fig. 1. Values for $22: 6 n-3 / 22: 5 n-6$ (a) and the proportions of 20:4n-6 (b) in piglet brain ( $\square$ ), liver $(\square)$ and retina $(\boldsymbol{\Lambda})$ at birth when sows were offered increasing amounts of dietary salmon oil. Data points represent means with their standard errors represented by vertical bars. For details of diets and procedures, see p. 463 and Table 1.

models where dietary $n-3$ fatty acid supply has been modified either by feeding the dam or supplying the neonatal animal with formula milks at a time when brain growth is still taking place. In piglets fed formula milks to which either 0,2 or $6 \mathrm{~g}$ menhaden fish oil were added (Arbuckle et al. 1991), responses in brain 22:6n-3 and $22: 5 n-6$ were quadratic in nature and similar to those found the present experiment, although there was no depression in brain 20:4n-6. In suckling mice (Huang et al. 1992; Wainwright et al. 1992) whose dams were fed increasing amounts of a $20: 5 n$-3-enriched fish oil, decreases in brain $20: 4 n-6$ and increases in $22: 6 n-3$ proportions were curvilinear in nature. Bourre et al. (1993) observed curvilinear increases in brain $22: 6 n-3$ in rat pups whose dams had been fed increasing amounts of bovine brain phospholipids and corresponding decreases in $22: 4 n-6$ and $22: 5 n-6$, although only small changes in 20:4n-6 were observed. Finally, in rat pups (Ward et al. 1998) offered formula milks containing increasing amounts of single-cell microbial oil containing primarily $22: 6 n-3(0,0.4$ and $2.4 \%$ total fatty acids), curvilinear responses in brain $20: 4 n-6$ and in the $22: 6 n-3 / 22: 5 n-6$ value were observed in response to increasing $22: 6 n-3$. In the different studies cited, the responses in brain and liver $22: 6 n-3$ (increasing to a plateau) and $22: 5 n-6$ (decreasing to a minimum value) were consistent and similar to those in the current study. Changes in 20:4n-6 were in general more variable.

In the experiment of Cordoba et al. (2000) reductions in neonatal mortality were observed despite a reduction in piglet birth weight as a result of feeding $16.5 \mathrm{~g}$ salmon oil $/ \mathrm{kg}$ to sows throughout pregnancy. It was proposed that the observed reduction in birth weight was related to a depression in tissue 20:4n-6 status as a result of feeding salmon oil. In human infants Carlson et al. (1992, 1993) found a positive correlation between $20: 4 n-6$ status and birth weight and first-year growth; these authors in a later study (Werkman \& Carlson, 1996) attributed the adverse effects on $20: 4 n-6$ status to the $20: 5 n-3$ content of fish oil, as in this study a fish oil containing a low concentration of $20: 5 n-3$ did not reduce $20: 4 n-6$ status. However, in studies using piglets fed formula milks supplemented with a low 20:5n-3 oil (Alessandri et al. 1998) or rat pups fed a purified 22 : 6n-3 supplement (Ward et al. 1998), reductions in $20: 4 n-6$ status were observed, suggesting that it was the overall contribution of long-chain $n-3$ polyunsaturated fatty acids that was responsible for the reduction in $20: 4 n-6$ status. Although tissue 20:4n-6 status can be maintained by feeding sources of $20: 4 n-6$ such as single-cell microbial oils (Huang \& Craig-Schmidt, 1996; Ward et al. 1998), this approach is impractical in sow nutrition, and therefore to avoid a depression in 20:4n-6 status, use of a lesser amount of oil than that used by Rooke et al. (2001) would be desirable. Inspection of Fig. 1 shows in the present experiment that reduction of the oil inclusion to $10 \mathrm{~g} / \mathrm{kg}$ produced a similar increase in $22: 6 n-3$ status whilst reducing the decline in 20:4n-6. An inclusion of $5 \mathrm{~g}$ oil $/ \mathrm{kg}$ gave a lesser response in $22: 6 n-3$ but again ameliorated the decline in 20:4n-6. In contrast to Cordoba et al. (2000) no depression in piglet birth weight was observed in the current experiment as the amount of salmon oil fed increased. Since Cordoba et al. (2000) fed salmon oil throughout gestation, any effect of salmon oil on piglet birth weight in the present experiment was probably masked by differences in litter size which would have been established before the experimental diets were introduced. However, there were differences between treatments in brain weight such that brain weight $(\mathrm{g} / \mathrm{kg})$ was at a maximum when $10 \mathrm{~g}$ oil $/ \mathrm{kg}$ was included in the diet and then declined when $20 \mathrm{~g} / \mathrm{kg}$ was 
included. Arbuckle et al. (1991) have also observed a depression in absolute but not relative brain weight in formula-milk-fed piglets when high levels of fish oil were included in the diet; similarly, high levels of $22: 6 n-3$ in the diet have been associated with reduced visual function in guinea-pigs (Weisinger et al. 1996). From this discussion it can be concluded that inclusion of $10 \mathrm{~g}$ salmon oil $/ \mathrm{kg}$ diet should be sufficient to ensure responses in piglet mortality, although this level would have to be confirmed by further experimentation.

Nutritional guidelines for pigs (Agricultural Research Council, 1981; National Research Council, 1998) do not give any requirements for $n-3$ fatty acids, as it is assumed that diets normally contain adequate amounts of these fatty acids. The fact that feeding the sow $18: 3 n-3$ does not result in increased incorporation of $22: 6 n-3$ into piglet tissues in utero (Rooke et al. 2000), that supplementation with fish oil containing 22:6n-3 increases piglet tissue $22: 6 n-3$ and reduces $22: 5 n-6$ indicating alleviation of a deficit in $22: 6 n-3$, and that neonatal mortality is reduced by feeding the sow marine oil (Cordoba et al. 2000) suggests that there may be a requirement for pre-formed $22: 6 n-3$ during pregnancy for optimum function of the new born piglet. Including $10 \mathrm{~g}$ salmon oil $/ \mathrm{kg}$ in the diet of the pregnant sow was the optimum inclusion in the current experiment on the basis of obtaining maximum deposition of $22: 6 n-3$ in piglet tissues and maximum brain size whilst minimising reductions in 20:4n-6 status. Feeding this amount of salmon oil was equivalent to approximately ( $\mathrm{g} / \mathrm{sow}$ per $\mathrm{d}$ ) $2.420: 5 n-3$ and $3.622: 6 n-3$. In terms of DE intake this level was equivalent to approximately $0.6 \% \mathrm{DE}$ intake (0.5\% total energy). Recently, Leskanitch \& Noble (1999) estimated from a literature survey (based on data from growing pigs and by analogy with that from human subjects) a requirement for $20: 5 n-3$ and $22: 6 n-3$ for pigs weighing $50-110 \mathrm{~kg}$ of $0.2 \%$ total dietary energy, which would be equivalent to $0.25 \% \mathrm{DE}$. Similarly, an adequate intake for the pregnant woman has been estimated to be $0.35 \%$ dietary energy (Simopoulos et al. 2000). The higher estimate derived here was probably caused by several factors: the greater demands for $22: 6 n-3$ by the developing fetus; low efficiency of transfer of dietary fatty acids from the diet to the fetus, estimated to be 0.02 of intake; deposition of $22: 6 n-3$ in maternal adipose tissue (Rooke et al. 2000, 2001).

In conclusion the present experiment has shown that the deposition of piglet tissue $n-3$ polyunsaturated fatty acid in utero in response to increasing inclusion of salmon oil in the diet of the pregnant sow is curvilinear in nature, and that under the conditions of the experiment an addition of $10 \mathrm{~g}$ oil/kg diet was considered to be optimal, allowing an estimate of the dietary requirements for $20: 5 n-3$ plus $22: 6 n-3$ for the pregnant sow to be $0.6 \%$ dietary DE.

\section{Acknowledgements}

We thank the following: Linda Birnie and Hugh Hamilton and his staff for the care of the pigs at Tillycorthie Pig Unit; Ian McKay for technical assistance. SAC receives financial support from the Scottish Executive Environment and Rural Affairs Department. The authors are grateful to Dr Ian Pike and the International Fishmeal and Oil Manufacturers Association for financial assistance.

\section{References}

Agricultural Research Council (1981) The Nutrient Requirements of Pigs, Slough, Berks: Commonwealth Agricultural Bureaux.

Alessandri J-M, Goustard B, Guesnet P \& Durand G (1998) Docosahexaenoic acid concentrations in retinal phospholipids of piglets fed an infant formula enriched with long-chain polyunsaturated fatty acids: effects of egg phospholipids and fish oils with different ratios of eicosapentaenoic acid to docosahexaenoic acid. American Journal of Clinical Nutrition 67, 377-385.

Arbuckle LD, Rioux FM, Mackinnon MJ, Hrboticky N \& Innis SM (1991) Response of (n-3) and (n-6) fatty acids in piglet brain, liver and plasma to increasing, but low, fish oil supplementation of formula. Journal of Nutrition 121, 1536-1547.

Ashworth CJ \& Pickard AR (1998) Embryo survival and prolificacy. In Progress in Pig Science, pp. 303-326 [J Wiseman, MA Varley and JP Chadwick, editors]. Nottingham: Nottingham University Press.

Bourre J-M, Dumont O \& Durand G (1993) Brain phospholipids as dietary sources of $(n-3)$ polyunsaturated fatty acids for nervous tissue in the rat. Journal of Neurochemistry 60, 2018-2028.

Campbell FM, Gordon MJ \& Dutta-Roy AK (1998) Placental membrane fatty acid-binding protein preferentially binds arachidonic and docosahexaenoic acids. Life Sciences 63, 235-240.

Carlson SE, Cooke RJ, Werkman SH \& Tolley EA (1992) First year growth of preterm infants fed standard compared to marine oil n-3 supplemented formula. Lipids 27, 901-907.

Carlson SE, Werkman SH, Peeples JM, Cooke RJ \& Tolley EA (1993) Arachidonic acid status correlates with first year growth in preterm infants. Proceedings of the National Academy of Sciences USA 90, 1073-1077.

Christie WW (1982) Lipid Analysis: Isolation, Separation, Identification and Structural Analysis of Lipids, 2nd ed. Oxford: Pergamon Press.

Christie WW, Noble RC \& Moore JH (1970) Determination of lipid classes by gas chromatography procedure. Analyst 95, 940-944.

Clandinin MT, Chappell JE, Leong S, Heim T, Swyer PR \& Chance GW (1980) Intrauterine fatty acid accretion rates in human brain: implications for fatty acid requirements. Early Human Development 4, 121-129.

Cordoba R, Pkiyach S, Rooke JA, Edwards SA, Penny PC \& Pike I (2000) The effect of feeding salmon oil during pregnancy on causes of piglet deaths prior to weaning. In Proceedings of the British Society of Animal Science 2000, p. 105, Penicuik, Midlothian: British Society of Animal Science.

Huang M-C \& Craig-Schmidt MC (1996) Arachidonate and docosahexaenoate added to infant formula influence fatty acid composition and subsequent eicosanoid production in neonatal pigs. Journal of Nutrition 126, 2199-2208.

Huang Y-S, Wainwright PE, Redden PR, Mills DE, BulmanFleming B \& Horrobin DF (1992) Effect of maternal dietary fats with variable $n-3 / n-6$ ratios on tissue fatty acid composition in suckling mice. Lipids 27, 104-110.

Innis SM (2000) Essential fatty acids in infant nutrition: lessons and limitations from animal studies in relation to studies on infant fatty acid requirements. American Journal of Clinical Nutrition 71, 238S-244S.

Kurlak LO \& Stephenson TJ (1999) Plausible explanations for effects of long chain polyunsaturated fatty acids (LCPUFA) on neonates. Archives of Diseases in Childhood 80, F148-F154. 
Leskanitch CO \& Noble RC (1999) The comparative roles of polyunsaturated fatty acids in pig neonatal development. British Journal of Nutrition 81, 87-106.

Ministry of Agriculture, Fisheries and Food (1992) Analysis of Agricultural Materials, 2nd ed. London: H.M. Stationery Office.

Ministry of Agriculture, Fisheries and Food (1993) Prediction of the Energy Value of Compound Feedingstuffs for Farm Animals, London: MAFF Publications.

National Research Council (1998) Nutrient Requirements of Swine, 10th revised ed. Washington, DC: National Academy Press.

Nettleton JA (1995) Omega-3 Fatty Acids and Health, New York: Chapman and Hall.

Passingham RE (1985) Rates of brain development in mammals including man. Brain Behavior and Evolution 26, 167-175.

Raclot T, Groscelas R, Langin D \& Ferre P (1997) Site-specific regulation of gene expression by $n-3$ polyunsaturated fatty acids in rat white adipose tissue. Journal of Lipid Research 38, $1963-1972$.

Roehe R \& Kalm E (2000) Estimation of genetic and environmental risk factors associated with pre-weaning mortality in piglets using generalised linear mixed models. Animal Science 70, 227-240.

Rooke JA, Bland IM \& Edwards SA (1999) Relationships between fatty acid status of sow plasma and that of umbilical cord and plasma and tissues of newborn piglets when sows were fed diets containing tuna oil or soyabean oil in late pregnancy. British Journal of Nutrition 82, 213-221.

Rooke JA, Shanks M \& Edwards SA (2000) Effect of offering maize, linseed or tuna oils throughout pregnancy and lactation on sow and piglet tissue composition and piglet performance. Animal Science 71, 289-299.

Rooke JA, Sinclair AG \& Edwards SA (2001) Feeding tuna oil to the sow at different times during pregnancy has different effects on piglet long chain polyunsaturated fatty acid composition at birth and subsequent growth. British Journal of Nutrition 86 , $21-30$.

Simopoulos AP, Leaf A \& Salem N (2000) Workshop statement on the essentiality of and recommended dietary intakes for omega- 6 and omega-3 fatty acids. Prostaglandins, Leukotrienes and Essential Fatty Acids 63, 119-121.

Sweasey D, Patterson DSP \& Glancy EM (1976) Biphasic myelination and the fatty acid composition of cerebrosides and cholesterol esters in the developing central nervous system of the domestic pig. Journal of Neurochemistry 27, 375-380.

Takahashi Y \& Ide T (2000) Dietary $n-3$ fatty acids affect mRNA level of brown adipose tissue uncoupling protein 1, and white adipose tissue leptin and glucose transporter 4 in the rat. British Journal of Nutrition 84, 175-184.

Uauy R, Mena P \& Rojas C (2000) Essential fatty acids: structural and functional role. Proceedings of the Nutrition Society 59, $3-15$.

Varley M (1995) The Neonatal Pig. Development and Survival, Wallingford, Oxon: CAB International.

Wainwright PE, Huang YS, Bulman-Fleming B, Dalby D, Mills DE \& Redden P (1992) The effects of dietary $n-3 / n-6$ ratio on brain development in the mouse: a dose response study with long-chain fatty acids. Lipids 27, 98-103.

Ward GR, Huang YS, Bobik E, Xing H-C, Mutsaers L, Auestad N, Montalto M \& Wainwright P (1998) Long-chain polyunsaturated fatty acid levels in formulae influence deposition of docosahexaenoic acid and arachidonic acid in brain and red blood cells of artificially reared neonatal rats. Journal of Nutrition 128, 2473-2487.

Weisinger HS, Vinger AJ \& Sinclair AJ (1996) The effect of 22:6(n-3) on the electroretinogram of the guinea pig. Lipids $\mathbf{3 1}$, $65-70$.

Werkman SH \& Carlson SE (1996) A randomised trial of visual attention of preterm infants fed docosahexaenoic acid until nine months. Lipids 31, 91-97. 